\title{
What make teenagers happy? An exploratory study using indigenous psychology approach
}

Primasari, Ardi

Center for Indigenous \& Cultural Psychology, Faculty of Psychology, Universitas Gadjah Mada, Yogyakarta, Indonesia (primasari.ardi@gmail.com)

Yuniarti, Kwartarini Wahyu $\bowtie$

Center for Indigenous \& Cultural Psychology, Faculty of Psychology, Universitas Gadjah Mada, Yogyakarta, Indonesia (kwartarini_yuniarti@yahoo.com)

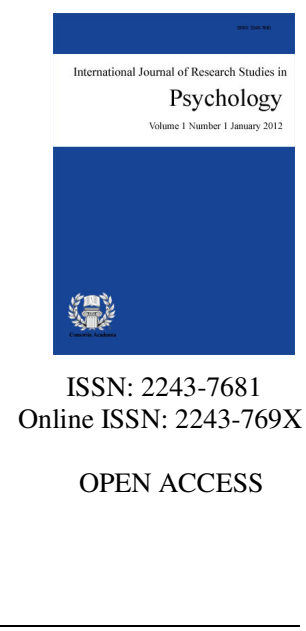

Received: 9 November 2011
Available Online: 10 February 2012

Revised: 18 January 2012

Accepted: 25 January 2012

\section{Abstract}

The aim of this research was to explore what make teenagers happy. The study was a survey on the total number of 467 high school students (males=198, females=269). An open ended questionnaire was used to learn what makes teenager happy. The data was analyzed using indigenous psychological approach. Preliminary coding, categorization, axial coding and cross-tabulation were run accordingly. The respondents' answers were analyzed using descriptive analysis. Results showed that there were three elements of the source of teenager's happiness, those are: (1) relations with others (50.1\%) consisting of events concerning their families, relations with friends, and events related to love and being loved; (2) Self-fulfillment (32.67\%) consists of events related to achievement, the use of leisure time, and money; (3) Relation with God $(9.63 \%)$ consists of spiritual events that involve the relations between teenagers and God. This study gave the insight that family-bond remain importance. Their being teenagers does not shift the reference into peer groups, rather than that, family is the main source of their happiness. It is also concluded that all are nothing but social engagement.

Keywords: happiness; Indonesian teenagers; indigenous psychology; family; self-fulfillment 


\section{What make teenagers happy? An exploratory study using indigenous psychology approach}

\section{Introduction}

Almost everyone wants happiness (Argyle, 2001), because happiness is important (Lyubomirsky \& Sheldon, 2005; Boven, 2005) and is an indicator for the quality of life (Nozick, 1989 as cited in Haller \& Hadler, 2006). The claim was strengthened by research done by Heady \& Veehoven (1989), which stated that people will be more satisfied with their live, able to accept the distance between hope and reality, and have a better performance. On the other hand, an unhappy person will be more prone to depression, suicide, anxiety, and delivers poor working performance and relations (Ruebenstein, Heeren, Housman, Rubin, \& Stechler as cited in Santrock, 1995).

The importance of happiness is also strengthened by Lu and Gilmour (2004) who stated happiness as a goal. Most people also hope that their live will have a happy ending (Chan \& Lee, 2006). Everyone will at least think about happiness once in a day (Freedman as cited in Lyubomirsky \& Sheldon, 2005).

The interest of studying happiness is increasing. In the last two decades, psychologists begin to grow interest to examine happiness scientifically (Easterlin, 2003). Argyle (2001) also stated that the research with happiness as a topic had been conducted since the 1960s. For example, in 1965, an American survey organization, The Pattern of Human Concerns - an international survey organization, conducted a survey with 23,875 respondents. In the year of 1969 The Structure of Psychology Well Being, used a NORC survey to study happiness. In 1976 Campbel, Convers and Rogers, studied The Quality of American Life from the survey of a Research Center at the University of Michigan. In 1967 Wilson published a happiness literature review in the Psychology Bulletin, and in the year 1984, Diener also conducted the same review and renewed it until the year of 1999. Compton (2005) stated that in the year 1967 publication related to the study of happiness was relatively limited.

The elaboration above showed that happiness is an interesting subject to study. There are various ways for an individual to obtain happiness. A few arguments about the source of happiness became the debate among experts. Hill (2004) and Oswald (1997) argued that most people would be happier if they are rich. Nonetheless, happiness is not only related to wealth as stated by Drakopoulos (2007) who also stated that possessions have no correlation with the level of happiness. The result of a research conducted by Haller and Hadler (2006) and Lelkes (2002), concluded that people with higher level of spirituality will be happier, meanwhile Francis, Ziebert, and Lewis (2003) argued that there are no correlation between happiness and spirituality. Aside from the previous elaboration, there are a few things which can make people happy such as friendship (Demir, Ozdemir, \& Weitekamp, 2006), health (Perneger, Hudelson, \& Bovier, 2004), and the forgiving nature (Maltby, Day, \& Barber, 2005).

Some researchers assessed the source of happiness by connecting it to the stages of individual development. The source of happiness of the elderly lies in their social network (Chan \& Lee, 2006; Gray, Rukumnuaykit et al., 2008) meanwhile the happiness on adults revolve around health, family, and relations (Perneger et al., 2004). Meanwhile the source of happiness on children is affected by love and favour (Park \& Peterson, 2006).

Research on happiness in Indonesia has been conducted many times. Based on the researchers' observation, most of the research tends to be explanatory or confirmatory, which are explaining the casual relationship to examine a hypothesis (Singarimbun, 2008). For example, the research about teenagers' happiness evaluated from dignity and materialism (Purnama \& Hastjaryo, 2006), happiness evaluated from self acceptance and social support (Sumarno, 2005), but in Indonesia, research using Indigenous Psychology, about teenagers was hardly found. The approach tries to understand people (mind, feelings, and behavior) within the context that encompass 
What make teenagers happy? An exploratory study using indigenous psychology approach

the local meaning from their own perspective. The goal of using this approach was to apply the result of the research contextually, so that it will minimize the cultural bias in the application (Moordiningsih, 2010).

On the teen stages, according to Mappiare in Purnama dan Hastjaryo (2006) the things that make teenagers happy are: going somewhere during holidays with some friends or families, visiting a conservatory area, achieving self development, succeed in school or gaining a chance to get a higher education. Besides that, teenagers also become happier if they can attain a good relation with other people, bond with friends, have new friends, engage in sports, games, cycling, and being useful to other people. However, not all teenagers can achieve happiness. Gullota and Adams (2005) recorded that at least $20 \%$ of the teen population is discontented. One of the factors that cause discontent among teenagers is the lack of friendship (Santrock, 1995). Apart from that, Santrock (1995) added that teenagers with discontent will have a higher risk of committing suicide. Therefore, it is imperative to heed the happiness on teenagers. Teenagers' happiness has a great impact for their next stages of live (Bernades, 1997). The assessment on teenagers' happiness mentioned above is inside the context of Western culture. So what about the happiness for teenagers in Indonesia? This study aimed to explore what make teenagers happy.

\section{Methods}

\subsection{Study participants}

The study participants of this study were a total number of 467 senior high school students in Yogyakarta, Indonesia, aged between 14-18 years old. The subjects consist of 198 males, 269 females.

\subsection{Instrument of the study}

The instrument used in the survey of this study was an open-ended questionnaire, which was developed by Kim (2009) focusing on Happiness. The research was conducted by the Center for Indigenous and Cultural Psychology (CICP) at the Faculty of Psychology, Universitas Gadjah Mada. Cultural and linguistic validation was performed previously and followed up with group discussions among students to ensure that the participants get the main understanding of the questions.

\subsection{Data Analysis}

The data was analyzed using indigenous psychological approach. Preliminary coding, categorization, axial coding and cross-tabulations were run accordingly. The process of categorization was conducted by combining the respondents' answers which have similarities. In the process of categorization, started from the large categories and perfected until smaller categories. Result shows that large category means that it consist of specific categories; whilst the smaller category consist of specific categories that had been generalized. The early phases in coding, according to Tukiran (2008) was to get familiar with the subjects' answers, before determining the code and category. These phases have been done for every question or variable within the questionnaire, one by one. The cross-tabulation shows the responses from a group of samples. The analysis is done by dividing research variables into categories based on a frequency table (Effendi \& Manning, 2008).

\section{Results}

Based on the categorization of the data, it was concluded that the source of teenagers' happiness consists of 8 sources. From the total of 467 respondents in the research, 146 respondents $(31.26 \%)$ stated that they are happy because of their families, 132 respondents $(28.26 \%)$ because of achievement, 45 respondents $(9.63 \%)$ because of spirituality/religion, 43 respondents $(9.20 \%)$ because of friends, 19 respondents $(4.06 \%)$ because of their leisure time, 12 respondents $(2.6 \%)$ because they receive money. 


\section{Table 1}

Source of teenagers' happiness $(N=467)$

\begin{tabular}{|c|c|c|}
\hline Categories & Frequency & Percentage \\
\hline Family & 146 & $31.6 \%$ \\
\hline Achievement & 132 & $28.26 \%$ \\
\hline Spirituality & 45 & $9.63 \%$ \\
\hline To love and be loved & 45 & $9.63 \%$ \\
\hline Friends & 43 & $9.20 \%$ \\
\hline Leisure time & 19 & $4.06 \%$ \\
\hline Money & 12 & $2.6 \%$ \\
\hline Others & 25 & $4.91 \%$ \\
\hline Total & 467 & $100 \%$ \\
\hline
\end{tabular}

Based on the evaluation of the data through field verification employing focus group discussion, the conclusion was that the family became the source of teenagers' happiness because the family consist of people who are relatively closer to the teenagers, those who know and accept them for who they are, consist of people who can be trusted by the teenagers, those who educate, those who guide and direct the teenagers. Moreover, family becomes the ones who helped the teenagers when they face hardship and the family also gives love to the teenagers. Achievement becomes the source of happiness for teenagers because it is a form of gratitude from the teenagers towards their parents, the pride of achieving something, a sense of relief when getting what they wanted, and imbues them with optimism in facing the future. Spirituality (relation with God) becomes a source of happiness for teens because it creates a sense of security and protection, tranquility and enjoyment when following religious creeds, the feeling of luck when praying, and God is believed to be the place for lamentation, and they believe that religion can motivate teenagers to become better, to guide, and to improve their quality of life.

The event of loving and be loved becomes the source of teenager's happiness because the teenagers feels glad when they receive care from someone they adore, they feel an increase in their self worth, they feel more appreciated and understood, they feel special, can reduce pain (sadness), creates a unique sense of gratification, increase in motivation and resulting in the harmonic relations with the people around them. The relation with their friends contributes to the teenagers' happiness because friends can help during times of hardship, can give support, and can drive out loneliness, as a place to share thoughts, feeling refreshed when they are with their friends, and friends becomes their self identity. A part from the explanations given earlier, leisure time also contributes to teenagers' happiness because they can use their leisure time to get rid of boredom and focus on their hobbies. While money can be one of the sources of happiness because money can fulfill teenagers' wishes and needs, money can give a sense of security, to accomplish certain plans, increase their prestige or dignity, motivates them to invent and can also be used to strengthen friendship.

From the data above a conclusion can be made, that there are 3 main sources of teenager's happiness, namely: (1) the relation with other people, consisting of the relations with family and friends, the event of loving and being loved. From 467 respondents in this research, the ones stating family as their source of happiness are 146 people (31.6\%), loving and being loved 45 respondents (9.63\%), friends 43 respondents $(9.20 \%)$, when totaled it tallied into 234 respondents (50.1\%) an astonishing fact. (2) Self fulfillment. The authors found that one source of happiness are a fulfilled self. Translated into the condition where the person is satisfied by their choices or their accomplishment. When it was re-examined with the verified data, it is proven that achievement, money and leisure time did gave a sense of gratification. In this research, from 467 respondents, 123 of them stated achievement $(28.26 \%)$, some 19 respondents stated leisure time (4.06\%), and some 12 respondents $(2.6 \%)$ stated money can create happiness. (3) Relations with God (9.63\%) were identified also as a source of happiness. It showed the existence of relationship between humankind and God, both in the forms of spiritual activities and contemplations of life, which is showing the gratitude to God. 


\section{Discussion}

Results of this research showed that relationship with other people is the most contributing factor in teenagers' happiness, relations with family as well as relations with friends and the events of loving and being loved, in which the three are the result of interrelation between individuals with other people. The result of the research after data re-evaluation concluded that family became the source of teenagers' happiness because the family consists of people, who are relatively close to the teenagers, those who know and accept them for who they are, consist of people that can be trusted by the teenagers, those who educate, those who guide and direct the teenagers. Moreover, the family becomes the ones that helped the teenagers when they face hardship and the family also gives love to the teenagers. Relationship with friends contributes to the teenagers' happiness because friends can help during times of hardship, can give support, and can drive out loneliness, as a place to share thoughts, feeling refreshed when they are with their friends, and friends influence their self identity. The event of loving and being loved become the source of teenager's happiness because the teenagers feel glad when they receive care from someone they adore, they feel as if they have got a better self-esteem, they feel more appreciated and understood, they feel special, can reduce pain (sadness), create a unique sense of gratification, increase in motivation and resulting in the harmonic relations with the people around them.

These findings are consistent with the research conducted by Uchida, Norasakkunkit, and Kitayama (2004) who found evidence that in Asian countries the main drive to obtain happiness is to accomplish communal happiness. In Asia the communities tend to focus on the bonding among each other. The key word for the happiness in the Eastern Culture is togetherness or relationship. Lu \& Gilmour (2004) stated that happiness is the result of relations with other people. In family and friends, there are the events of loving one another and becoming the source of support. Social relations also have tremendous effect for happiness and other aspects in the meaning of life, and can be the single largest factor.

It is also found that self-fulfillment comprising of achievement, the use of leisure time, and money have a significant contribution towards happiness. The three are classified into the elements of self fulfillment, because all three gave a surmountable amount of happiness and joy for the teenagers themselves, also including teenagers' dignity. Achievement becomes the source of happiness for teenagers because it is a form of gratitude from the teenagers towards their parents, the pride of achieving something, a sense of relief when getting they wanted, and imbues them with optimism in bracing their future. Leisure time contributes to teenagers' happiness because they can use their leisure time to get rid of boredom and focus on their hobbies. While money can be one of the sources of happiness because money can fulfill teenagers' wishes and needs, money can give a sense of security, to accomplish certain plans, increase their prestige or dignity, motivate them to invent and can also be used to strengthen friendship

Despite all, this was also found that the achievement of teenagers was not only aimed at personal happiness, but also as a dedication to other people, their parents for example, as well as money as the source of happiness. Money is not only used to fulfill personal desires and needs, but also to nurture friendship. In this aspect, it is also shown that money still correlates to social relation. Leisure time on the other hand, aside to gain satisfaction or joy, is not spent alone but also to do activities related to other people, like playing football or hanging out with their friends.

Seeing that evidence, the author stated that happiness in Indonesia does not belong to a person only. Uchida et al. (2004) described that personal happiness in the Eastern society can spark jealousy within the society. As mentioned before, in a collective culture like Indonesia, Triandis as cited in Susana (2006) stated that self is seen as a social representation in which a person is considered as a part of a social unit.

Previously, Caplin (2006) revealed what he called as self gratification, which defined as a self satisfaction and pleasure, a pleasure derived from the fulfillment of personal need, one of which is a need associated with prestige (self esteem). Seligman (2005) called it as gratification, an activity that makes us feel 'enriched.' 
Primasari, A. \& Yuniarti, K. W.

Previous research in Indonesia showed that the need of pride for teenagers is one of the ways to attain happiness (Purnama \& Hastjarjo, 2006).

Based on the data, the author emphasized that what is meant by the source of happiness element "self fulfillment" does not only focus on self, because "self fulfillment" on individuals cannot be detached from other people. The relationship with God also became one of the elements of teenagers' source of happiness. Coan in Compton (2005) call it as self transcendence. While Caplin (2006) stated that the transcendental is connected to spirituality, link with spirit, soul, religious fervor, faith, devotion, correlates to transcendental values in opposition against physical and carnal values. Teenagers believe that there is a reciprocal relation between individuals and God. This is caused by the existence of positive emotions when teenagers relate to God, the sense of security, composure, comfort, feelings of fortune, and even as a form of coping against pressure.

In Indonesia, education also facilitates teenagers to have a relation with God. It is supported by the education curriculum that provides the religion subject, starting from kindergarten; elementary; junior high school; senior high school; even university. This research showed that the relationship between teenagers and God are a contributing factor in teenagers' happiness. A study is not without limitation, and the same applies for this study, especially when it comes to the sampling methods. To see a more comprehensive result, the sampling needs to be representative.

\section{Conclusions}

This study gives the insight that family-bond remain importance. Their being teenagers does not shift the reference into peer groups, as it would be found in the Western literature, rather than that, family is the main source of their happiness. It is also concluded that all are nothing but social engagement. Figure 1 gives the summary of the study's results, which enable us to see the map of what makes adolescents happy and how those components interact with each other.

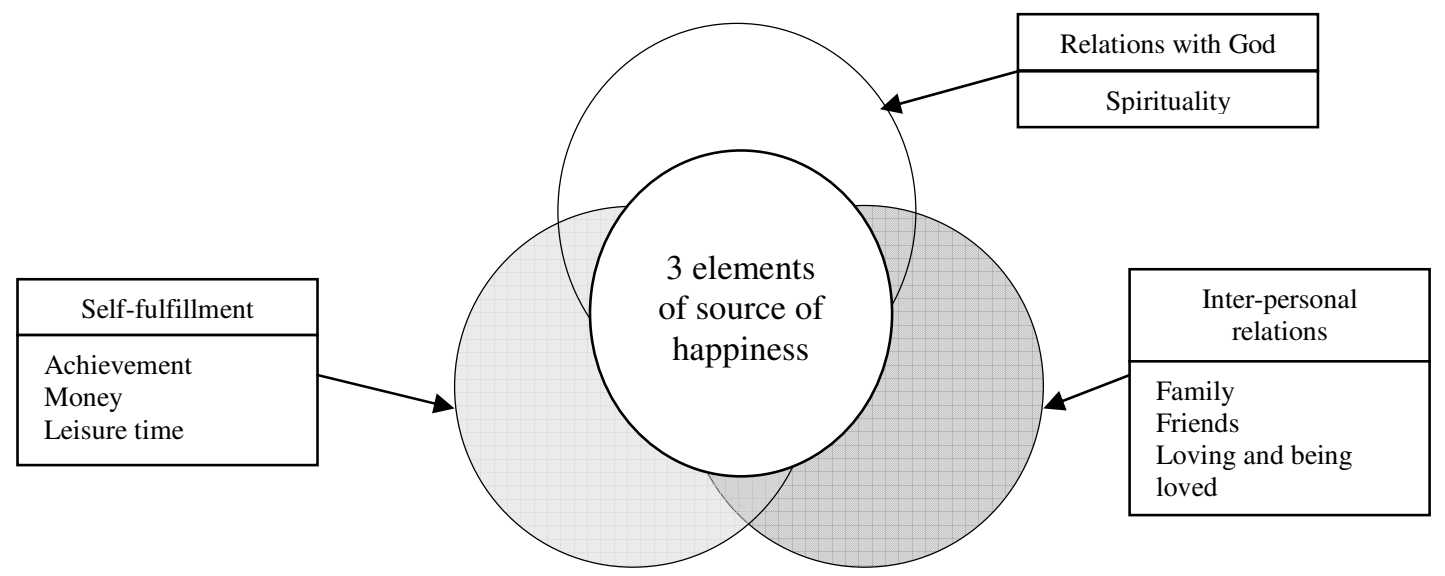

Figure 1. 3 Elements of "the source of happiness"

Note: A part of this article was presented in the 9th Biennial Conference of Asian Association of Social Psychology at Kunming, China, on July 26-31, 2011.

Acknowledgment: This study was supported by the data from the Center for Indigenous and Cultural Psychology at the Faculty of Psychology, Universitas Gadjah Mada, Yogyakarta, Indonesia. 


\section{References:}

Amawidyawati, S. A. G, \& Utami, S. M. (2007). Religiusitas and psychological well being pada korban gempa [In Indonesian] (Religiosity and psychological well being on earthquake victims). Jurnal Psikologi UGM, 34(2), 164-176.

Argyle, M. (2001). The psychology of happiness. New York: Routledge.

Azwar, S. (2007). Metode Penelitian [In Indonesian] (Research method). Yogyakarta: Pustaka Pelajar.

Batuadji, K. (2007). As Moksharthamjagadhita: Study Etnografis tentang Well-Being pada Warga Ashramgandhi Etnis Bali [In Indonesian] (Etnographic study about well-being, on Ashramgandhi residents' Balinese ethnic). Yogyakarta: Universitas Gadjah Mada.

Bernades, J. (1997). Family studies an introduction. London: Routledge.

Berns, R. M. (2007). Child, family, school, community: Socialization and support ( $7^{\text {th }}$ ed.). Australia: Wadsworth. Bornstein, M. H. (2002). Handbook of parenting: Practical issues in parenting. (2 ${ }^{\text {nd }}$ ed., Vol. 5) London:

Lawrence Erlbaum Associates Publisher.

Boven, V. L. (2005). Materialism and the pursuit of happiness. Review of general psychology, 2, 132-142. $<$ http://dx.doi.org/10.1037/1089-2680.9.2.132>

Carr, A. (2004). Positive psychology the science of happiness and human strengths. USA: Brunner-Routledge.

Chan,Y. K., \& Lee, R. P. L. (2006). Network size, social support and happiness in later life: A comparative study of Beijing and Hong Kong. The Journal of Happiness Study, 7, 87-112. $<$ http://dx.doi.org/10.1007/s10902-005-1915-1>

Compton, W. C. (2005). An introduction to positive psychology. USA: Wadsworth.

Croosley, A., \& Langdridgen, D. (2005). Perceived sources of happiness: A network analysis. The Journal of Happiness Study, 6,107-135. <http://dx.doi.org/10.1007/s10902-005-1755-z>

Coopersmith, S. (1967). The antecedent of self-esteem. San Francisco: W.H. Freeman \& Company.

Csikszentmihalyi, M. (1999). If we are so rich, why aren't we happy? American Psychology, 55, 821-827. $<$ http://dx.doi.org/10.1037/0003-066X.54.10.821>

Davis, E., Kean, P., \& Eccles, J. S.( 2005). Influence and challenges to better parent- School collaborations. In E. N. Dalam Patrikakou, R. P. Weissberg, S. Redding, \& H. J. Walbergg (Eds.). School-family partnerships for children's success. Teacher College: Columbia University.

Day, R. D. (2003). Introduce family processes $\left(4^{\text {th }}\right.$ ed.) London: Lawrence Erlbaum Associates Publisher.

Dey, I. (1993). Qualitative data analysis a user-friendly guide for social Scientists. London \& New York: Taylor $\&$ Francis or Routledge's collection.

Demir, M., Ozdemir, M., \& Weitekamp, L. A. (2007). Looking to happy tomorrows with friends: Best and close friendship as they predict happiness. The Journal of Happiness Studies, 8, 224-271. $<$ http://dx.doi.org/10.1007/s10902-006-9025-2>

Drakoppoulos, S. A. (2007). The paradox of happiness: towards and alternative explanation. The Journal of Happiness Study, 9, 303-315. <http://dx.doi.org/10.1007/s10902-007-9054-5>

Easterlin, R. A. (2002). The income-happiness relationship. USA: University of California.

Easterlin, R. A. (2003). Explaining happiness. Proceedings of the National Academy of Sciences of the United States of America, 199, 11176-11183. <http://dx.doi.org/10.1073/pnas.1633144100>

Effendi, S., \& Manning, C. (2008). Prinsip-prinsip analisis data [In Indonesian] (The principles of data analysis). In M. Singarimbun \& S. Effendi (Eds.), Metode Penelitian Survai. Jakarta: LP3ES.

Francis, L. J., Ziebertz, H. G., \& Lewis, C. A. (2003). The relationship between religion and happiness among German student. The Journal of Pastoral Psychology, 51, 273-333. <http://dx.doi.org/10.1023/A:1022529231234>

Gray, R. S., Rukumnuaykit, P., Kittisuksathit, S., \& Thongthai, V. (2008). Inner happiness among Thai elderly. The Journal of Cross Cultural Gerontology, 23, 211-224. $<$ http://dx.doi.org/10.1007/s10823-008-9065-7>

Gullota, T. P, \& Adams, G. R. (2005). Handbook of adolescence behavioral problems. New York: Springer Science Business Media, Inc. <http://dx.doi.org/10.1007/b102865> 
Primasari, A. \& Yuniarti, K. W.

Haidt, J. (2006). The happiness hypothesis putting ancient wisdom and philosophy to the test of modern science. London: Arrow Books.

Haller, \& Hadler. (2006). How social relation and structures can produce happiness and unhappiness: An international comparative analysis. Social Indicators Research, Springer.

Hammer, L. B., \& Neal, M. B. (2008). Sandwich generation. Encyclopedia of social problems. Retrieved October 21, 2009 from http://www.sage-ereference.com/socialproblems/Article_n492.html

Hayes, N. (2000). Doing qualitative analysis in psychology. New York: Psychology Publisher.

Hetherington. E. M., \& Hagan, M. S. (2002). Parenting in divorced and remarried families. In M. H. Bornstein (Ed.), Handbook of parenting: Being and becoming a parent ( $2^{\text {nd }}$ ed. Vol. 3) (pp. 287-316). London: Lawrence Erlbaum Associates Publisher.

Headey, B., \& Wooden, M. (2004). The effects of wealth and income on subjective well-being and ill-being. Melbourne: Melbourne Institute of Applied Economic and Social Research.

Hill, R. (2004). Happiness in Canada since World War II. Social Indicator Research, 65, 109-123. $<$ http://dx.doi.org/10.1023/A:1025596332111>

Hurlock, E. B. (2004). Psikologi Perkembangan. Suatu Pendekatan Sepanjang Rentang Kehidupan [In Indonesian] (Developmental Psychology. An Approach of a Lifetime) (Alih Bahasa : Istiwidayanti \& Soedjarwo). Edisi Kelima. Jakarta : Penerbit Erlangga.

Kim, U., \& Hwang, K. (2006). Indigenous and cultural psychology, understanding people in context. Springer Science Business Media, Inc.

Kim, U., \& Berry, J. W. (1993). Indigenous psychologies: Research and experience in cultural context. Newbury Park: Sage

Kim, U. (2009). Indigenous psychological analysis of trust/happiness/self/achievement/parent-child relationshp/coping with disaster. Unpublished manuscript, Inha University, Incheon, Korea.

Lelkes, O. (2002) Tasting freedom: Happiness, religion and economic transition. London: The Research Centre for Analysis of Social Exclusion.

Lyubormrsky, S., King, L., \& Diener, E. (2005). The benefit of frequent positive affect: Does happiness lead to success. American Psychological Association Psychology Bulletin, 131(6), 803-855.

Lyubormrsky, S., \& Sheldon, K. M. (2005). Pursuing happiness: The architecture of sustainable change. Review of General Psychology, 2, 111-131. <http://dx.doi.org/10.1037/1089-2680.9.2.111>

Lu, L., \& Gilmour, R. (2004). Culture and conceptions of happiness: Individual oriented and social oriented SWB. Journal of Happiness Studies, 5, 269-2914. <http://dx.doi.org/10.1007/s10902-004-8789-5>

Lu, L. (2001). Understanding happiness: A look into the Chinese folk psychology. Journal of Happiness Studies, 2, 407-432. <http://dx.doi.org/10.1023/A:1013944228205>

Lu. L., Gilmour, R., \& Kao, F. K. (2001). Cultural value and happiness: An east and west dialogue. Journal of Happiness Studies, 141, 477-493.

Maltby, J., Day, L., \& Barber, L. (2005). Forgiveness and happiness. The differing contexts of forgiveness using the distinction between the hedonic and eudaemonist of happiness. Journal of Happiness Studies, 6,1-13. <http://dx.doi.org/10.1007/s10902-004-0924-9>

Messier, \& Pamela, M. (2008). Family. Encyclopedia of social problems. Retrieved October 21, 2009 from http://www.sage-ereference.com/socialproblems/Article_n206.html

Monks, F. J., Knoers, A. M. P., \& Haditono, S. R. (2006). Psikologi Perkembangan: Pengantar Dalam Berbagai Bagiannya [In Indonesian] (Developmental psychology: Introductions in its various segments). Yogyakarta: Gadjah Mada University Press.

Moordiningsih. (2010). Optimisme mengkristalkan kearifan lokal. Dalam 50 Tahun Himpunan Psikologi Indonesia [In Indonesian] (Optimism will crystallize indigenous wisdom. In the 50 years of the Indonesian psychology community). In A. Supratiknya \& T. Susana (Eds.). Redefinisi Psikologi Indonesia dalam Keberagaman (The redefinition of Indonesian psychology in diversity). Solo: HIMPSI.

Oswald, A. J. (1997). Happiness and economic performance. England.

Park, N., \& Peterson, C. (2006). Character strengths and happiness among young children: content analysis of parental descriptions. Journal of Happiness Studies, 7, 323-341. 
What make teenagers happy? An exploratory study using indigenous psychology approach

$<$ http://dx.doi.org/10.1007/s10902-005-3648-6>

Perneger, T. V., Hudelson, P. M., \& Bovier, P. A. (2004). Health and happiness in young Swiss adults. The Journal of Quality of Life Research, 13, 171-178. <http://dx.doi.org/10.1023/B:QURE.0000015314.97546.60>

Purnama, A., \& Hastjaryo, T. D. (2006). Happiness among adolescence by self-esteem and materialism value. Unpublished Masteral Thesis, Gadjah Mada University, Yogyakarta.

Santrock, J. W. (1995). Life span development. USA: Brown Communications, Inc.

Santrock, J. W. (1995). Life span development (7th ed.) Boston: McGraw-Hill College.

Seligman, M. E. P. (2005). Authentic happiness, menciptakan kebahagiaan dengan psikologi positif [In Indonesian] (Authentic happiness, creating happiness with positive psychology). Bandung: PT Mizan Pustaka.

Singarimbun, M., \& Effendi, S. (2008). Metode penelitian survay [In Indonesian] (Survey research method). Jakarta: Pustaka LP3ES Indonesia.

Singarimbun, M. (2008). Metode dan proses penelitian [In Indonesian] (Methods and research process). In S. M. Dalam \& S. Effendi (Eds.), Metode penelitian survay [In Indonesian] (Survey research method). Jakarta: Pustaka LP3ES Indonesia.

Suardiman. (1995). Menyiasati perilaku remaja untuk tampil prima dan bahagia [In Indonesian] (Handling the teenage behavior to perform perfectly and happily). Bulletin Psikologi. 2, 58-65.

Sumanto. (2006). Kajian psikologis kebernaknaan hidup [In Indonesian] (Psychological assessment of the significance of life). Bulletin Psikologi, 14(2).

Susana, T. (2006). Somatisasi dalam budaya kolektivitas ditinjau dari teori pemahaman elson: Kritik terhadap psikoanalisis klasik [In Indonesian] (Somatization in a collective culture observed from Elson's understanding theory: The critique on classic psychoanalysis). Bulletin Psikologi UGM, 14(32).

Teeple, T. W. C. (2008). Family, nuclear. Encyclopedia of social problems. Retrieved October 21, 2009 from http://www.sage-reference.com/socialproblems/Article_n210.html

Tukiran. (2008). Mengkode data (Coding data). In S. M. Dalam \& S. Effendi (Eds.), Metode penelitian survai [In Indonesian] (Survey research method). Jakarta: Pustaka LP3ES Indonesia.

Uchida, Y. (2004). Cultural constructions of happiness: Theory and empirical evidence. Journal of Happiness Studies, 5, 223-239. <http://dx.doi.org/10.1007/s10902-004-8785-9> 
Primasari, A. \& Yuniarti, K. W. 